\title{
AZ EURÓPÁVAL VALÓ AZONOSULÁS ÉRTÉKALAPOZOTTSÁGA
}

\author{
Grünhut Zoltán \\ (Közgazdaság- és Regionális Tudományi Kutatóközpont)
}

A tanulmány beérkezett: 2020. február 11., opponálás: 2020. február 20. - 2020. április 29., véglegesítve: 2020. június 30.

ÖSSZEFOGLALÓ

\begin{abstract}
Jelen tanulmány törekvése az Európáról mint célra irányuló politikai projektről szóló, politikai-közéleti diskurzusokat és ideaalkotásokat befolyásoló elméleti okfejtések csoportosítása, érvelésük hátterében alapvető gondolkodásmódbeli különbségek azonosítása, utóbbiak ontológiai szintű értékekre történő visszavezetése, illetve mindezen összefüggések empirikus vizsgálata abban az értelemben, hogy vajon az eltéró értékeket preferáló, s aszerint eltérően gondolkodó egyének valóban másként azonosulnak-e Európával, illetve saját európaiságukkal. A tanulmány arra kíván rávilágítani, hogy az Európával való azonosulás szubjektív beállítódás (értékek és gondolkodásmódok) függvénye, amely összefüggés ott lappang az Európáról szóló, szisztematizált tudományos elméletek mondanivalójának hátterében is. Ezeknek ezért elsősorban reproduktív és rekonstruktív hozzájárulásaik vannak.
\end{abstract}

Kulcsszavak: Európa — európaiság — gondolkodásmódok — Másik — értékek - integrációs elméletek

\section{EURÓPA-FINALITÁSOK ÉS AZOK ELMÉLETI LOGIKÁJA}

Az európai egységesülés gondolata hosszú történelmi múltra tekint vissza (Bóka, 2001). Miközben e koncepciók leginkább víziókat adók voltak, a tudományos igényû szintetizálásuk pedig elsősorban eszmetörténeti jellegü, addig a II. világháborút követően meginduló szupranacionális intézményformálás már szisztematikusabb elméletalkotást követelt meg. Az így megszülető integrációs elméletek főként politikatudományi (illetve ahhoz kapcsolódóan gazdaság- és jogtudományi) inspirációkból építkeztek. Elsődleges céljukként azt fogalmazták meg, hogy teoretikus „színteret” adjanak az európai integrációnak, illetve az azzal összefüggő dinamikáknak (Arató, 2019). A különböző integrációs elméletekre saját koncepció-evolúciójaként tekintő diszciplína, az 
Európa-tanulmányok - némi leegyszerüsítéssel - három fókuszpont szerint csoportosítja teoretikus bázisát: értelmezések arról, hogyan kellene múködnie Európának (normatív elméletek); vizsgálati keretek arról, miként múködik Európa (leíró elméletek); interpretációk arról, mi jellemzi az egyes európai szakpolitikákat (Diez-Wiener, 2004). Miközben az előbbi két csoportba tartozó elméletek továbbra is feladatuknak tekintik, hogy képet alkossanak Európáról, felvázolják tehát az Európa-finalitás - célra irányulás - vízióját, addig a harmadik kategória értelmezései ettől tartózkodnak, s csak szakpolitikai folyamatokkal foglalkoznak (integrációs elméleti besorolásuk ezért kétséges)."

E tanulmány számára a normatív és leíró Európa-koncepciók a fontosak. Előbbieknek három típusa különíthető el. A föderatív értelmezések a szuverenitás megosztását képviselik, a szupranacionális intézményi struktúrák létrehozását szorgalmazzák, továbbá mindezek feltételeként az európai identitás - nemcsak a művészeti-kulturális közösség, de az európai léptékű összetartozásérzés - megerősítésének feltételeit kutatják (Burgess, 2000; Rosamond, 2000). Az újfunkcionalista teóriák a már létező európai intézményhálózat fejlődési pályáit igyekeznek megérteni. Ezen elméletek is az integráció mélyítését tartják szem előtt, ám „programadás” helyett arra helyezik a hangsúlyt, hogy különböző mechanizmusok (ún. spillover dinamikák) miként gerjesztik az európai intézményprogressziót (Haas, 1958; Stroby-Jensen, 2007). Alaptételük, hogy a multilaterális együttmúködés stabilizálódása előmozdítja az állami felsővezetőkkel szemben a megbízott technokraták kompetenciaszerzését. E csoport a pragmatikus ügykezelést, a hatékony, gyakorlatias problémamegoldást tekinti elsődleges feladatának. Folyamatos tevékenységének velejárója az a mechanizmushatás, ami a multilaterális rendszer állandó tökéletesítését, eredményességének fokozását célozza. E spillover dinamikáknak különböző dimenziói vannak: funkcionális (egyik szakpolitikáról a másikra átterjedő intézményszervezési minták), politikai (mind több szektor és szereplő bevonása az ügykezelésekbe), intézményi (új szervek alakulása, az elitek kompetenciabővülése, intézményidentitásuk formálódása - Európa-bürokratizmus), földrajzi (a multilaterális együttmúködés területi bővülése), kulturális (európai identitás kibontakozása, az állampolgárok többrétegü hovatartozása) (Arató, 2019). Végezetül a normatív elméletek harmadik típusát a konstruktivista-kritikai megközelítések adják, amelyek rendszerint társadalomelméleti perspektívával igyekeznek gazdagítani az integrációs szemléletet (Grünhut, 2017). Ezen irányzaton belül a kozmopolita Európáról szóló elméletek a legkidolgozottabbak (lásd:

* Az integrációs elméletek sajátos típusát adják az ún. differenciált integrációs teóriák, amelyek abban az értelemben próbálják újragondolni a meglévő koncepciókat, hogy valóban lehetséges-e a teljes EU-ra, illetve annak folyamataira és céltételezéseire egységes elméleti kereteket rávetíteni, avagy helyesebb több teoretikus síkban azonosítási kísérleteket tenni (lásd: Koller, 2012, 2019). E szemléletben tehát keverednek a normatív és leíró Európa-finalitások. Talán éppen ezért leginkább elméleti és gyakorlati következményư hibrid megoldásról van itt szó. 
Beck-Grande, 2007; Delanty-Rumford, 2005; Rumford, 2007, 2008), de vannak posztstrukturalista, feminista és normatív institucionalista kezdeményezések is. Közös jellemzője e teóriáknak, hogy az európai integráció előrehaladását, egy posztnemzeti fordulat lehetőségét - politikai intézkedések helyett - átfogó társadalmi változások részeként képzelik el. Ennek jegyében rajzolják meg Európa-képüket modernizációs narratívába ágyazva, az elidegenedés, eldologiasodás és elismerés társadalomelméleti szövetéhez kapcsolva, vagy a Másikhoz való viszonyulás és a szubjektum emancipálódása tükrében.

A leíró jellegú integrációs elméletek - miként az már szóba került - nem a "kívánatos lenne”, hanem a "mi van” lencséjén keresztül gondolkodnak Európáról. E koncepciók közös talapzata a realista szemlélet, ami azt hirdeti, hogy a nemzetközi rendben továbbra is a nemzetállamok a legmeghatározóbb aktorok, így mindenféle multilaterális együttmúködés alapja a nemzeti érdekek érvényesítése és a nemzeti kultúrák primátusa, továbbá az azokra épülő közös örökségek ápolása (Nugent, 1999). E tudományos szemlélet tehát erélyesen visszahelyezi a nemzetet mind az európai integrációs elméletek kereteibe, mind általában az Európáról való gondolkodás feltételei közé (Cini, 2007). A kormányközi értelmezések abból indulnak ki, hogy a multilaterális együttmúködésekben érdekelt tagállamok a belpolitikai folyamataik tükrében alakítják külpolitikai stratégiájukat, mégpedig racionális kritériumokat, legkitüntetettebb elvként a kormányon maradást követve (Moravcsik, 1994, 1998). A kormányközi elmélet kétségbe vonja az újfunkcionalisták spillover-tételét, miszerint a „nagypolitika” (a nemzeti kormányok) legfőbb reprezentánsai bármit is szívesen kiengednének a hatáskörükből a szupranacionális technokraták javára. Éppen ellenkezőleg: lappangó kompetencia- és szuverenitás-rivalizálás a jellemző, nemzetállami dominancia mellett. Az újintézményi megközelitések (illetve hasonló érveket használva a többszintú kormányzás teóriája) ugyanígy arra keresik a választ, miként illeszkednek egymáshoz a szupranacionális, nacionális, továbbá a szubnacionális szintek intézményei. A fókusz azon van: milyen vertikális jellegú (le- és felfelé ható), valamint horizontális mechanizmusok okozzák a szakpolitikai harmóniát/diszharmóniát, egyáltalában az integráció közpolitikai (policy), hatalomgyakorlási (politics) és intézményrendszeri (polity) vetületű konvergenciáját/divergenciáját, továbbá a különböző kulturális közegek közeledését/távolodását (DiMaggio-Powell, 1991). Az új intézményi megközelítések legalább négy típusa rendelkezik önálló elméleti kerettel. A történelmi institucionalista érvelés a mintakövetés logikáját hangsúlyozza: eszerint az intézmények fejlődése inkább graduális, a formális és az informális intézménytípusok összhangja kulcsfontosságú a rendszerfunkció szempontjából, miközben az átfogó reformpontok éppen ezért megrázkódtatással járhatnak, ilyenkor ugyanis referenciavesztés történhet (North, 1990; Fiori, 2002). A racionális döntés teóriája a kalkulálhatóság logikáját követi: azt állítja, az ágensek és struktúrák kölcsönhatásában az egyéni érdek- 
követés a generatív tényező, vagyis az intézmények változását a mérhetőség, kiszámíthatóság, összehasonlíthatóság racionalizmusa mozgatja (Shepsle, 2005; Weingast, 1998). A szociológiai jellegú intézményi szemlélet ezzel szemben az ágensek és struktúrák viszonyrendszerét a normakövetés logikája tükrében interpretálja: az emberek tehát a kulturális korlátokhoz (értékekhez, konvenciókhoz, narratívákhoz, viselkedési szabályokhoz, rutinokhoz stb.) igazítják formális intézményeiket, amelyek emiatt hiába alakíthatók könnyen és gyorsan, tényleges dinamikáik mindig a sokkal nehezebben változtatható normákhoz kötöttek maradnak (March-Olsen, 1989; Hall-Taylor, 1996). Negyedik típusként pedig beszélni kell a diszkurzív intézménykoncepcióról is, amely szerint a struktúrák ideák formájában léteznek az ágensek gondolkodásában, s ezért a megváltoztatásuk esélyeit az ideákról szóló diskurzusokon keresztül lehet adekvátan vizsgálni (Schmidt, 2008, 2010 és 2017).

Mind a normatív, mind a leíró jellegú integrációs elméletek olyan tudományos konstrukciók, amelyek nemcsak befolyásolják a politikai-közéleti diskurzusokat, de eredendő impulzusaikat is okvetlenül onnan merítik. Az Európafinalitással összefüggő érveléseik ezért legalább annyira társadalmi percepciókból kibontakoztatott, szisztematikus elméletté szintetizált megismerések, mint amennyire koncepciókként ugyanezeket a percepciókat igyekeznek teoretikus sémákba rendezni. Egy elméletalkotás már a legelső gondolattól mindig, eredendően elméleti konstrukcióktól terhes (szubjektív) (Guzzini, 2017). Nem előzetes koncepcióktól mentes, mert maga az elméletalkotó nem lehet "üres" szubjektum. Az Európa-finalitással kapcsolatban a fenti normatív és leíró elméletek két úton járnak. Előbbiek „többet akarnak” Európából, az egységesülés útjait, módjait keresik, illetve olvassák ki a különböző folyamatokból. Ez egy Európa-központú elméleti perspektíva, jövőorientált, a jelen meghaladhatóságát hirdeti. A leíró teóriák ezzel szemben a „van”, azaz a fennálló állapot leírására törekednek, szem előtt tartva azt, hogy az integrációt nemzetállamok hozták létre, amelyek tudatos érdekkövetésük céljából engedték át szuverenitásuk egy részét Európának. Ennek a konstellációnak a felülírhatatlanságát teoretikus érvrendszerükkel folyamatosan megerősíteni igyekeznek e megközelítések. Ez tehát nemzetközpontú szemlélet; a jövőben nem az az érdekes ezen interpretációk számára, hogy az mit fog meghaladni, sokkal inkább az: mi marad hosszabb távon is érvényes a múltból és jelenből. A politikai-közéleti diskurzusokban e két Európa-finalitás polarizáltan ölt testet: a kozmopolita alapállású Európai Egyesült Államok áll szemben a nacionalista elvű Nemzetek Európájával. Természetesen van megannyi köztes árnyalódás és átszíneződés ezen ideaorientációs szélsőpontok között, de ez nem változtat azok iránytújellegén. A következőkben azt mutatja be a tanulmány, hogyan illeszkedik az Európa-finalitás e két szélsőpontja a mélyebb szintü egyéni gondolkodásmódokhoz. 


\section{AZ EURÓPA-FINALITÁSOK GONDOLKODÁSMÓDBELI TALAPZATAI}

Az Európai Egyesült Államok és a Nemzetek Európája mint egymással rivalizáló koncepciók arra vonatkozólag, hogy az európai integrációnak milyen úton kellene haladnia, számos közpolitikai, hatalomgyakorlási, és politikai intézményrendszeri aspektus tekintetében szorgalmaznak merőben ellentétes alternatívákat. Ezeket nem szándékozik összevetni a tanulmány, mivel abból a feltételezésből indul ki, hogy a két ütköző Európa-finalitást ennél alapvetőbb szintû különbség taszítja egymástól. Másféle értelmezéseket kínálnak, mivel összeegyeztethetetlen gondolkodásmódon alapuló percepciók és interpretációk formájában azonosítják a maguk körüli világot. Hogy ezt átlássuk, észre kell vennünk: az eszmék konstruált értelmezések, amelyek alkotóiktól, illetve attól a társadalmi-kulturális közegtől, amelyet e szóvivők képviselnek, soha nem függetlenek (Collier, 1994). Az ideákban az alkotó szóvivők egyéni szubjektivitása jelenik meg, ezért az értelmezett tartalmak kifejezik a szóvivők és hívők jellemző gondolkodásmódját. Egy eszmében sohasem a valóság tükröződik vissza, hanem mindig az alkotó jelenik meg; az ideák nem reprezentálnak, hanem prezentálnak (Rorty, 1989). A két Európa-finalitás közötti különbséget ezért jelen írás abban igyekszik megragadni, hogy azok hogyan azonosítják a tárgyi, természeti, s társadalmi világot, miközben nem foglalkozik azzal, mit mondanak erről. Ez a hogyan maga a gondolkodásmód, amelynek akármi is a tárgya, mindig arra vonatkozik, hogy az én miként látja a tárgyi, természeti, s társadalmi közegét, illetve ahhoz viszonyítva önmagát (Rorty, 1991). A gondolkodásmód az én megértésének módja (narratív és performatív konstruálása) a Másikhoz viszonyulva (Brons, 2015). Kozmopolita perspektívában mindez a Másik elismerésén keresztül zajlik: az én előtérbe helyezi azt, ami közös benne a Másikkal, s így az elfogadhatóvá válik. Nacionalista perspektívában az azonosulásnak ez az elismerési komponense háttérbe szorul, ezért a Másiktól való megkülönböződés lesz a gondolkodásmód alapja. E szemléleti különbség eltérő szubjektív beállítódásokra utal: a kozmopoliták önmeghaladó, a nacionalisták én/Mi-fókuszú diszpozíciókra támaszkodnak.

A gondolkodásmód (mint ideákon keresztüli világazonosítás) sajátos megismerési múvelet, amely értékalapozottsággal bír. Mielőtt ezen értékalapokra összpontosítanánk, fontos tisztázni a megismerések és praxisok merőben eltérő sémáját a fent nevezett két Európa-finalitás esetében. A kozmopolita perspektíva alapsémája a mind-mind elvet követi (Beck és Grande, 2007). E gondolkodásmód a pánrelációs felfogásból indul ki, miszerint minden mindennel összefügg a tárgyi, természeti és társadalmi világban (Rorty, 1998). Vagyis nemcsak az embertársak összetartozása releváns, valamennyi szubjektum emberi minőségének felismerése és tiszteletben tartása, de az is tudatosodik, hogy mi, azaz az egyének összessége természeti közegünkben, attól biológiailag- 
fizikailag elválaszthatatlanul létezünk, s folyamatosan tárgyakat használunk. Mindannyian benne élünk ebben a tárgyi, természeti, társadalmi világban: regisztráljuk, adminisztráljuk, értelmezzük, kritikailag meg- és felülvizsgáljuk, reflexív módon alakítjuk, vagyis folyamatosan konstruáljuk azt, szubjektív résztvevőkként (vö.: Kapitány és Kapitány, 2013). Egyedi és egyszeri emberi minőségünkben megteremtjük életfeltételeinket, szükségleteinket, ideáinkat, érzéseinket, viszonyrendszereinket stb. - önmagunkat. Eszerint a kozmopolita perspektíva második kulcseleme az antireprezentáció: semmi sem tükrözi vissza a valóságot, mert mi konstruáljuk azt (Rorty, 1979). Ebből viszont okvetlenül következik egy harmadik aspektus is: ha minden, ami tudatosult formát ölt szubjektív alkotásnak számít, akkor nincs objektív Igazság, csak közösen, konszenzuálisan megteremtett, mindig felülvizsgálható igazságosság (Rorty, 1998). Ezen antiesszencialista felfogás kizárja azt, hogy megkérdőjelezhetetlen Igazságokká lehessenek emberi ésszel felfogott és nyelvileg kifejezett, mindezzel elkerülhetetlenül szubjektívvá váló tudások. Ha van is objektív tudás, azt az emberi tudással nem lehet összevetni, mert ehhez ismernünk kell, ami objektív jellegét azonnal és végérvényesen felszámolja (Vandenberghe, 2014).

A kozmopolita perspektíva e három elvszerü felfogása keretezi a mind-mind sémát. A nacionalista Európa-finalitás és mögöttes elméletei ennek éppen az ellenkezőjét képviselik a vagy-vagy alapséma szerinti logikákkal és szemantikákkal (Beck és Grande, 2007). Abból indulnak ki, hogy minden egyre pontosabban és aprólékosabban megérthető. Ehhez az egyénnek semlegességre és észszerûségre kell törekednie. Leginkább egy megfigyelői pozícióból képes az individuum e részletek objektív megitélésére, összevetésére (vö.: Lukács, 1971). A vagy-vagy séma - orientáló módon - világos kódok szerinti értékmérésre ösztönzi az egyént: Jó/Rossz, Igaz/Hamis, Előnyös/Káros stb. Tulajdonképpen mindennek kialakul a bináris értékmércéje, amelyek alá közös nevezőként bekúszik az Értékes/Értéktelen kvantitatív tartalmú szűrője. Ez utóbbi a kvalitatív jellegú bináris kódokat is számszerûsíti. Mindezzel a gazdaság, mégpedig a kapitalista termelési mód szerinti gazdaság válik az alapjává minden viszonyrendszernek a tárgyi, természeti, s társadalmi világon belül (Grünhut et al., 2019a). A (pénz-, vagy tőke-, vagy jövedelmezhetőség-alapú) csereérték-számításra hagyatkozó racionális gondolkodási forma mindent eldologiasít, parciális elemeire bont fel, mert csak így lehetséges a partikularitások rendszerezése, szervezése, összevetése, kalkulálása (Jaeggi, 2014). Ez megszünteti a résztvevői jellegú pánrelációs összetartozást az Egésszel. Az egyén elszakad a tárgyi, természeti, s társadalmi világától, illetve önmagától is. A viszonyrendszereket a dologiasult csereérték és annak racionális számolása határozza meg, vagy-vagy sémát követő, világos jelentésadásokkal. Ahhoz, hogy ezen észszerúségre minél inkább támaszkodni lehessen, objektív Igazságokat szükséges tudni vélni az értékítéletek mögött. A valóság reflektív le- 
képezése lesz a cél. Ezért kezdi a csereérték-számítás alakítani az egyének tárgyi, természeti, s társadalmi viszonyrendszereit, ahelyett hogy ők maguk konstruálnák azokat (Grünhut et al., 2019a). Az Igazságokat esszenciákként tudatosítják maguk számára, s az egyének mindent megtesznek azért, hogy a saját igazságukat rákényszerítsék másokra.

A kozmopolita mind-mind és a nacionalista vagy-vagy gondolkodásmódok merőben eltérő alapsémái az elismerésnyújtással, illetve az elismerés-felejtéssel írhatók le. Honneth (1995) antropológiai jellegû társadalomkritikájában úgy érvel, hogy mielőtt kialakulna az újszülött megismerési tudata (a 9. hónap körül), már rendelkezik egy emocionális alapú kötődéssel a gondozója/gondozói felé. Ez az összetartozásérzés maga az elismerés. E beállítódás tehát minden emberben megvan, ám később a megismerési tudat formálódása következtében (komplex strukturális hatások miatt) elfelejtődhet. Honneth (2007) szerint, minél inkább háttérbe szorul az elismerés, annál jellemzőbbé válik az objektív semlegességre törekvő, racionális számításokat követő, megfigyelői kivonódás, ami a tárgyi, természeti és társadalmi világ eldologiasításával (instrumentális értékmérésével) jár. Az elismerés-felejtés több mint egocentrikus érdekkövetés (noha ebben ragadható meg a leghétköznapibb módon). Az egyén, a mindentől és mindenkitől elszakadtan álló individuum, résztvevői minőségében képtelen megalkotni világát és abban önmagát (Sik, 2018). Nem látja az Egész jelentőségét, s nem tudatosítja a Másik egyediségét. Elveszik a parciális dolgoknak való olyasféle jelentés-, illetve értékadásban, amit egy elvonatkoztatott és megcáfolhatatlan objektivitással próbál igazolni (Weiss, 2008). Ez a racionalitás nem tûr meg kétségeket, többértelmúségeket, kritikai reflexiókat. Egyféle Igazságot diktál, amitől nem lehet eltérni. Éppen ezért miközben felszámolja a Másik szubjektivitását, elsorvasztja az egyén szabadon konstituálható egyéniségét is. Csak a felcímkézhető, összemérhető és kiszámítható dolgok maradnak, amikkel egy önmagát szintén dologiasult módon értelmező egyén próbál racionálisan sáfárkodni. Az elismerés-felejtés egy kontemplatív pozícióba való kilökődés (Sik, 2018). Az egyén nem tud belehelyezkedni embertársai perspektívájába, mert nem is látja a Másikat. Csak a saját igaza létezik, vagyis az én, illetve az önmagát másokra kivetített Mi. Éppen ezért az egyén arra is képtelenné válik, hogy mások perspektíváján keresztül, többféle szemszögből lássa, értelmezze tárgyi és természeti világát. Az elismerés-felejtés következménye, hogy az egyén csak egyetlen magyarázatot, egyetlen jelentésadási érvrendszert, illetve ahhoz illően, csak egyetlen nyelvet és szótárt fogad el. E gondolkodásmód racionálisnak tûnik fel - s ezen észszerûség alternatíva nélküliként mutatkozik meg (Honneth, 2007). Azt sugallja: mindenki ezt követi, egyéni különbségek csak az informáltság szintje miatt, valamint az intellektuális belátási képesség következtében adódhatnak. Az eldologiasult világlátás ezért nem fogható fel sem erkölcstelenségként, sem episztemológiai kategó- 
riahibaként (Honneth, 2007). Túlterjed ugyanis a megismerésen, s eltorzítja az egyén ontológiai szintû, értékalapozottsággal bíró szubjektív beállítódását.

Az ezen, ellentétes gondolkodásmódokra visszavezethető kozmopolita és nacionalista Európa-finalitások okvetlenül egymástól különböző ideákat kínálnak. Jelen tanulmány a fentiek tükrében azt állítja: anélkül hogy részletesen elemeznénk az Európa-finalitások tartalmi mondanivalóját, már az ideaalkotás hogyanja kapcsán kimutatható radikális eltérésük egymástól. Az alkalmazott megismerések, amelyekból ezen, mind-mind, illetve vagy-vagy típusú értelmezési sémái következnek a tárgyi, természeti és társadalmi világnak, már eleve beszédesek, orientálóak az emberek számára. Egész egyszerúen azért, mert a kozmopolita és nacionalista Európa-finalitásokban olyan szóvivők szubjektív értelmezései jelennek meg, akik egy, jellemzően hasonló gondolkodású emberekből álló társadalmi közeget képviselnek (Grünhut, 2019a).

Éppen emiatt másodlagos jelentőségú, hogy mit mond a közpolitikai aspektusokról a kozmopolita Európa-finalitás, mert már a hogyan kérdése alapvetően eldönti, ki tud azonosulni ezen ideákkal; a hogyan, amely szerint közpolitikai stratégiákat és döntéseket széles bevonás alapján, konszenzust kereső diskurzusok nyomán kell meghozni (Beck-Grande, 2007). E közpolitikák nem törekednek reflektív Igazságokra, nem igénylik kétségbevonhatatlanul objektív szakértői vélemények támogatását (Beck, 2006). A hangsúly az igazságosságon van, vagyis azon, hogy minél több szereplő számára hasznos döntés szülessen. Többféle problémaértelmezés, többféle megoldás, többféle módszer létezhet, nincs szükség standardizált modellekre. Decentralizált, autonóm és partnerségi elvű együttmúködések révén kell előrelépni. A kozmopolita Európa-finalitás közpolitikai logikáiból következik, hogy a hatalomgyakorlás vonatkozásában az állampolgári részvétel (social engagement) alapvető jelentőségü (Balibar, 2003). A hatalomgyakorlásnak - mindig és minden szinten - átláthatónak és elszámoltathatónak kell lennie, azaz demokratikus kontroll alatt kell állnia. Nem alakulhatnak ki erőközpontok, amelyek jog- és hatásköröket, kompetenciákat sûrűsítenek össze maguk számára. Végezetül a kozmopolita Európa-finalitás a politikai intézményrendszer kapcsán arra helyezi a hangsúlyt, hogy a struktúrák folyamatosan változtathatóak; az intézményeknek az a funkciója, hogy az egyének kritikai ágenciáit ösztönözzék, s ezzel szubjektivitásuk kibontakozását elősegítsék (Grünhut, 2019b). A kozmopoliták szerint ágens és struktúra konstellációja nem antagonisztikus küzdelmet jelent, hanem reflexív és progresszív kölcsönhatást (Beck et al., 1994).

A nacionalista Európa-finalitás teljesen másként képzeli el az idealkotás hogyanját. Közpolitikai ügyekben az iránykijelölés és a döntéshozás tekintélyelvư logikákat követ, azaz egy érdekeltségei szerint összefüződött politikai, gazdasági, szakmai és civil elit kiváltságának tekinthető. Az alapvető problémaazonosítás nagyon szúk szereplői körben történik, s csak a megoldáskeresés nyitott szélesebb - lojálisakból álló és/vagy függőségi módon alárendelt - 
csoportok számára (Habermas, 2012). Ilyen módon biztosítják a hatalom tényleges birtokosai, hogy a közpolitikák határozottan kijelölt célokat kövessenek, világos ideológiai korlátok között. A diskurzusok keretezettek, egy kijelölt ideáról szólnak, így a kritikai meglátások teljesen új dimenziókat nem tudnak behozni. A szakértőknek tehát legitimációs feladatuk is van: igazolniuk kell, hogy az azonosított problémák valóban relevánsak, s helyesen feltételezettek. Éppen ezért kérdéseket megfogalmazó tudósokra nincs szükség, csak válaszalternatívákat kereső szakértőkre (Zizek, 2013). A hatalomgyakorlás mindezek miatt elitesedett, a társadalomtól elszakadt. Erősen centralizált minden struktúra, a jog- és hatásköröket kijelölt szervekhez rendelik, ám azok is vertikálisan rendezettek, vagyis az alsóbb szintú egységeknek csak végrehajtó feladatuk van. Demokratikus kontrollra korlátozott lehetőség adódik, mivel az egész rendszer transzparenciája kétséges. A hatalomgyakorlást áthatja az erôs állam eszméje és a vezérszellem (Habermas, 2009). A politikai szektor minden egyéb szférát (gazdaság, jog, kultúra, média, oktatás-kutatás stb.) maga alá rendel. Ez a biztosítéka annak, hogy egyetlen ideológia, egyetlen idearendszer, egyetlen esszenciális Igazság tudjon érvényesülni. E hatalomgyakorlási logika nem résztvevőnek, hanem racionális cselekvőnek tekinti az embereket, akik rögzített feltételek között felismerik, hogy mi észszerû számukra. Éppen ezért a nacionalista Európa-finalitás a politikai intézményrendszert statikusan látja (Habermas, 2006). Úgy érvel, ha a struktúrák egyértelmú referenciákat jelölnek ki, amelyek kritikai felülvizsgálatát csak alapos meggondolással hagyják jóvá, akkor az emberek könnyebben tudnak tájékozódni, világosabban látják-értelmezik a maguk körüli dolgokat, s így megismeréseik valamint praxisaik sokkal kiszámíthatóbbak lesznek - önmaguk és partnereik számára egyaránt. A jelentést hordozó struktúrákat ezért védenie kell a hatalomnak; a különféle bizonytalanságokra adott egyéni reflexióknak nem szubjektíveknek, hanem racionálisaknak kell lenniük - mégpedig egyféle objektív észszerúség tükrében.

\section{SCHWARTZ ÉRTÉKELMÉLETE}

A korábbiakban a tanulmány úgy érvelt, az Európa-finalitással kapcsolatban alternatív elképzeléseket kínáló normatív és leíró jellegú integrációs elméletek legalapvetőbb különbsége abban keresendő, hogy e teoretikus konstrukciók eltérő gondolkodásmódokra vezethetők vissza. Tehát maguknak az elméletadóknak a gondolkodásmódja eltérő, mégpedig azért, mert különböző társadalmi-kulturális közegeket képviselnek; olyanokat ahol inkább a kozmopolita mind-mind, avagy a nacionalista vagy-vagy a jellemző. Éppen ezért az Európafinalitással kapcsolatos integrációs elméletekre úgy indokolt tekinteni, mint amelyek szisztematikus teóriákba foglalják a politikai-közéleti diskurzusokban meglévő Európa-képeket. Az érintett integrációs elméleteket és a politikai- 
közéleti ideákat pedig az azonos talapzatú szubjektív gondolkodásmódok kapcsolják össze - a Másikról való gondolkodás mint világazonosítás. A kozmopoliták önmeghaladó, változásokra nyitott, jövőorientált gondolkodásmód tükrében azonosítják tárgyi, természeti és társadalmi világukat, míg a nacionalisták én/Mi-fókuszú, biztonságpreferált (protektív), s múlt-, illetve jelenbázisú logikákat-szemantikákat alkalmazva. Ezen eltérő szubjektív beállítódások értékalapozottsággal bírnak. Hogy ezt megvizsgálhassuk, röviden át kell tekintenünk az értékek jelentőségét. Ehhez Shalom H. Schwartz elméletét hívja segítségül az írás. Az alapvető emberi értékek koncepciója az egyik legkidolgozottabb, empirikus kutatásokhoz leggyakrabban alkalmazott szociálpszichológiai értékteóriának számít. Schwartz kiinduló tézise, hogy vannak olyan egyetemes érvényú értékek, amelyeket az emberek minden társadalmi közegben ugyanazon jelentésekkel azonosítanak (Schwartz és Bilsky, 1987). Ezen alapértékek igazolási tartalma tehát absztrakt és konstans, de mivel az egyének eltérő preferenciákat állítanak fel közöttük, ezért az individuális szinten különböző értékkészletek más és más módon befolyásolják az emberek gondolkodásmódját (Schwartz és Bilsky, 1990). Mindannyian értékek, mégpedig univerzális jelentőségű alapértékek mentén határozzuk meg önmagunkat - ez közös bennünk; viszont egyénileg eltérően ítéljük meg ezen értékek egymáshoz viszonyított relatív fontosságát - ez tesz diverz szubjektumokká minket. Schwartz $(1992,2005)$ az alapértékekkel kapcsolatos elméletét keretelv- és tételállítások mentén kezdi kibontani. Először is rögzíti, hogy az értékek három alapvető emberi igényre vonatkoznak: a szubjektum biológiai szükségleteire, a társas érintkezések koordináltságára, továbbá különféle csoportok túlélési (avagy jóléti és jólléti) törekvéseire (Grünhut et al. 2019b). Schwartz (2006) ezekből kiindulva határozza meg az értékekkel kapcsolatos hat alaptételét:

- Az értékek egyszerre racionális argumentumok és morális-emocionális tartalommal bíró hitek.

- Az értékek motiválják az egyént bizonyos vágyott célok elérésére (mit kell megvalósítani).

- De az értékek viszonyítási standardokként is funkcionálnak (hogyan kell megvalósítani azt).

- Az értékek absztrakt érvényüek, általában nem függvényei konkrét szituációknak, interakcióknak.

- Az értékek között relatív fontosság szerinti dinamikus összefüggés áll fenn, ami meghatározza a szubjektív értékválasztást, magát az egyéni értékkészletet.

- Az egyéni cselekvésben mindig több érték egyidejü hatása érvényesül.

Schwartz (1992) az értékek tíz típusát különbözteti meg:

1. Önállóság: az autonómia iránti természetes vágyban gyökeredzik. A következő fogalmakkal írható le: szabadság, függetlenség, kreativitás, önbecsülés. 
2. Ösztönzés: a változatosság iránti igényt jeleníti meg. Az újdonság- és kihíváskeresés, kockázatvállalás, továbbá a rutinoktól mentes élet élménye motiválja.

3. Hedonizmus: a szükségletek és vágyak kielégítésének érzéki öröme, az élvezetek keresése.

4. Elismerés: annak igénye, hogy a közeli és távolabbi partnereink fogadják el, hagyják jóvá, sőt jutalmazzák a cselekedeteinket. A következő fogalmakkal írható körül: ambíció, siker, érvényesülés.

5. Hatalom: a minél magasabb társadalmi státusz és presztízs elérése motiválja; dominanciára való törekvés emberek és erőforrások felett.

6. Biztonság: az egyén anyagi biztonságra, egészsége megőrzésére, személyes kapcsolatai stabilitására, valamint a szúkebb és tágabb társas közegében kialakult rend fenntartására vonatkozó igénye.

7. Konformitás: a társadalmi elvárásokhoz és normatív előírásokhoz való alkalmazkodás fontossága motiválja. Fogalmai: önfegyelem, engedelmesség, tisztelet, lojalitás.

8. Tradíció: a hagyományok, a közös tudások, valamint a kollektív hitek és tapasztalatok megőrzésének, ápolásának és továbbadásának fontosságát, a közösség iránti alázatot jeleníti meg.

9. Jóindulat: a szorosabb és intimebb relációk kiegyensúlyozottsága, megerősítése iránti igény, illetve az ezen interakciókban érintett felekről való gondokoskodás motiválja. Fogalmai: becsületesség, barátság, őszinteség, segítőkészség, megbocsátás.

10. Univerzalizmus: az embertársak jólétének és jóllétének fontossága, a társadalmi egyensúlyok biztosítása, a szociális konfliktusok konszenzusos kezelése, valamint a természeti környezet megóvása motiválja. A tolerancia, igazságosság, szolidaritás, kölcsönösség, béke, környezetvédelem, egyenlőség eszméivel írható körül.

Az egyéni értékkészlet szempontjából mind a tíz alapérték releváns, ám az egymáshoz viszonyított relatív fontosságukat tekintve szubjektumonként eltérően. Ezt az értékek közötti dinamikus kölcsönhatást Schwartz többféle módon is megragadja. Egyfelől hangsúlyozza, hogy az első öt érték énfókuszú, míg a második öt társadalomfókuszú jelentéstartalommal bír. Mindez nemcsak az egyéni igénytételezések és a közösségi-társadalmi viszonyrendszerek elkülönítését szolgálja, hanem az ezek közötti esetleges feszültségek lehetőségét is felveti. Ezt az összefüggést Schwartz úgy érzékelteti, hogy az alapértékeket rávetíti két tengelyre (1. ábra). Ezek bipolárisak, vagyis ellenpontokat jelenítenek meg. Az egyik ilyen tengely az önmegvalósítás, szemben az önmeghaladással. Előbbi az ént állítja a középpontba, míg utóbbi elhelyezi az ént az embertársak között. A másik tengelyen a változásra való nyitottság áll szemben a megőrzéssel, előbbi tehát a dinamikus progressziót képviseli, míg utóbbi a konzerválást. 
1. ábra. Schwartz értékmodellje

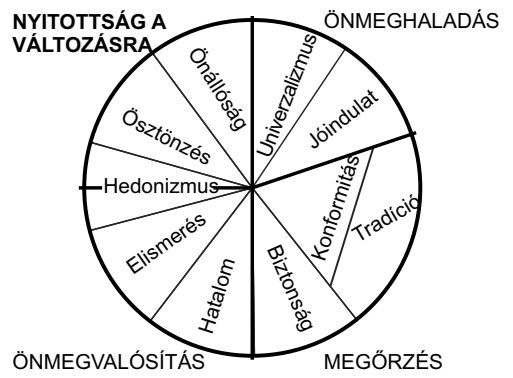

\begin{tabular}{|c|c|c|}
\hline Értékcsoport & Értékkategória & $\begin{array}{l}\text { Értéktípus } \\
\text { (alapérték) }\end{array}$ \\
\hline \multirow[t]{5}{*}{ Énfókuszú } & \multirow[t]{2}{*}{ Nyitottság a változásra } & Önállóság \\
\hline & & Ösztönzés \\
\hline & \multirow{3}{*}{ Önmegvalósítás } & Hedonizmus \\
\hline & & Elismerés \\
\hline & & Hatalom \\
\hline \multirow{5}{*}{$\begin{array}{l}\text { Társadalom- } \\
\text { fókuszú }\end{array}$} & \multirow[t]{3}{*}{ Megőrzés } & Biztonság \\
\hline & & Tradíció \\
\hline & & Konformitás \\
\hline & \multirow[t]{2}{*}{ Önmeghaladás } & Jóindulat \\
\hline & & Univerzalizm \\
\hline
\end{tabular}

Forrás: Schwartz (2006) alapján szerzői szerkesztés

Az ábráról azt tudjuk leolvasni, hogy Schwartz két értékcsoportot, négy értékkategóriát és tíz értéktípust különít el, s ezeket egy cikkelyekből álló körben foglalja össze. A körábrázolásnak is funkciója van, amennyiben kifejezi azt a logikát, miszerint az egyéni értékkészletben leginkább kitüntetett értékhez viszonyítva, mind balra, mind jobbra a körcikkelyeken haladva a többi értéktípus preferálása egyre csökken az ellenpontig (Grünhut et al., 2019b). Ebből persze az is következik, hogy nemcsak a két értékcsoport és a négy kategória szerint tartoznak össze az alapértékek, de bizonyos értéktípusok - noha eltérő csoportokban és kategóriákban szerepelnek - mégis közelebb állnak egymáshoz, mint másikak. Vagyis a körcikkelyek egymásmellettisége elméleti összefüggésekre reflektál. Schwartz (1992) ennek jegyében hangsúlyozza, hogy az önállóságnak és az univerzalizmusnak közös jelentéstartalma a szubjektív diverzitás elfogadása, az egyetlen perspektívából megfogalmazott magyarázat elutasítása, s helyette a több vélemény konszenzusára épülő igazságosság szorgalmazása. A hatalomnak és a biztonságnak közös nevezője a bizonytalanságoktól való félelem, illetve az azokon való olyasféle felülkerekedés, ami az egyén kontrollkapacitásaira támaszkodik. Az ösztönzésben és a hedonizmusban egyaránt megjelenik az individuális örömélmény, legyen az valamilyen újdonság keresése vagy vágykielégülés ûzése. Az elismerésben és a hedonizmusban ezzel szemben közös az önkényeztetés, előbbi érték esetében öntömjénezésként és öndicséretként, míg utóbbinál az élvezetek önboldogító szaporításaként. A jóindulat, valamint a tradíció és konformitás jelentéstartalmai tekintetében pedig azonosság fedezhető fel a közösséghez tartozás normativitásának különféle hangsúlyozásaiban, illetve a személyes relációk fontosságának kiemelésében.

Schwartz érvelése segít abban, hogy beazonosítsuk a kozmopolita és a nacionalista Európa-finalitások jellemző gondolkodásmódja mögött meghúzódó szubjektív beállítódásokat. Mint az fentebb kifejtésre került, amíg a kozmopolita perspektíva - önmeghaladó és változásra való nyitott módon - elismerés- 
sel van a Másik felé, addig a nacionalista szemlélet az ént/Mit állítja a középpontba és protektív logikákat követ, ami miatt a Másiktól határozottan elkülönül. Ezen eltérő gondolkodásmódok alapvetően különböző értékpreferenciák következményei. E feltételezés tükrében a kozmopolitáknak az önmeghaladást és a változásra való nyitottságot kell értékkészületükben kiemelniük, különösen két értéket, az univerzalizmust és az önállóságot preferálva. Ezzel szemben a nacionalisták szemléletét az ént/Mit középpontba állító önmegvalósítás és a fix referenciákat adó megőrzés dominálja, legfőképpen a hatalom és a biztonság értéktípusai.

\section{ADATOK ÉS EREDMÉNYEK}

A következőkben bemutatott empirikus elemzés célja megvizsgálni azt, hogy 18 európai uniós tagállam - köztük Magyarország - társadalma (1) jellemzően miként viszonyul a Másikhoz - inkább a kozmopolita, avagy inkább a nacionalista gondolkodásmód szerint? (2) ezen eltérő megismerési logikák és szemantikák hátterében valóban kimutatható-e egymással ellentétes szubjektív értékalapozottság? (3) a kozmopoliták és a nacionalisták valóban eltérő módon azonosulnak-e Európával? A felhasznált adatok az European Social Survey (ESS) 8. hullámából (2016) származnak.

Első lépésként egy hat itemből álló indexet mutat be az elemzés. Ez alapján lesz értékelhető a Másikhoz való viszonyulás, amelyet az EU, illetve a tagállamok társadalmi szintjén összegezve láthatunk alább. A hat itemre adható válaszok 0, 1 és 2 értékekkel ellátva kategorizálódnak (1. táblázat). A válaszadók kompozit indexértéke ennek alapján 0 és 12 között alakulhat. A kapott szám alapján a válaszadókat három csoportba sorolja az elemzés. Ezek: nacionalista én/Mi-fókuszúak, ambivalensek, kozmopolita önmeghaladók (2. táblázat). A Másikat három szempontból kívánja megragadni a vizsgálat: nők, melegek-leszbikusok, bevándorlók (Grünhut, 2019c). A bevándorlók általában a Mitôl mint kulturális-nyelvi közösségtől való idegeneket jeleníti meg; a melegek-leszbikusok mint a biológiailag „elrendelt” nemi orientációtól és az arra épülő tradicionális családmodelltól való idegenek relevánsak; a nők pedig a hagyományos patriarchális világértelmezéstől és a történelmileg rögzült (hím domináns) hatalomeredeztetéstől való idegenekként fontosak. 
1. táblázat. A Másikhoz való viszonyulás indexe

\begin{tabular}{|c|c|c|c|}
\hline \multirow[t]{2}{*}{ Változók } & \multicolumn{3}{|c|}{ Kategóriaértékek } \\
\hline & 0 & 1 & 2 \\
\hline $\begin{array}{l}\text { Ha kevés a munkalehetőség, a férfiaknak } \\
\text { elsőbbséget kellene élvezniük a munka- } \\
\text { vállalásnál }\end{array}$ & $\begin{array}{l}1 \text { - teljesen } \\
\text { egyetértek } \\
2-\text { egyet- } \\
\text { értek }\end{array}$ & $\begin{array}{l}3 \text { - egyet is } \\
\text { értek, meg } \\
\text { nem is }\end{array}$ & $\begin{array}{l}4-\text { nem } \\
\text { értek egyet } \\
5-\text { egyál- } \\
\text { talán nem } \\
\text { értek egyet }\end{array}$ \\
\hline $\begin{array}{l}\text { Hagyni kell, hogy a meleg férfiak, és a } \\
\text { leszbikus nők szabadon éljék az életüket } \\
\text { melegként és leszbikusként úgy, ahogy } \\
\text { akarják }\end{array}$ & $\begin{array}{l}4-\text { nem } \\
\text { értek egyet } \\
5-\text { egyál- } \\
\text { talán nem } \\
\text { értek egyet }\end{array}$ & $\begin{array}{l}3 \text { - egyet is } \\
\text { értek, meg } \\
\text { nem is }\end{array}$ & $\begin{array}{l}1-\text { teljesen } \\
\text { egyetértek } \\
2-\text { egyet- } \\
\text { értek }\end{array}$ \\
\hline $\begin{array}{l}\text { A meleg férfipárokat és a leszbikus női } \\
\text { párokat a gyermekek örökbefogadása } \\
\text { terén a heteroszexuális párokéval meg- } \\
\text { egyező jogoknak kellene megilletnie }\end{array}$ & $\begin{array}{l}4-\text { nem } \\
\text { értek egyet } \\
5 \text { - egyál- } \\
\text { talán nem } \\
\text { értek egyet }\end{array}$ & $\begin{array}{l}3 \text { - egyet is } \\
\text { értek, meg } \\
\text { nem is }\end{array}$ & $\begin{array}{l}1 \text { - teljesen } \\
\text { egyetértek } \\
2 \text { - egyet- } \\
\text { értek }\end{array}$ \\
\hline $\begin{array}{l}\text { Általában véve árt, vagy használ [adott } \\
\text { ország] gazdaságának, hogy más orszá- } \\
\text { gokból idejönnek élni emberek? (0 azt } \\
\text { jelenti „árt a gazdaságnak”, } 10 \text { pedig azt } \\
\text { „használ a gazdaságnak”) }\end{array}$ & $\begin{array}{l}\text { skálaértékek } \\
\text { 0-tól 3-ig }\end{array}$ & $\begin{array}{l}\text { skálaértékek } \\
\text { 4-től 6-ig }\end{array}$ & $\begin{array}{l}\text { skálaértékek } \\
\text { 7-től 10-ig }\end{array}$ \\
\hline $\begin{array}{l}\text { Mit mondana, [adott ország] kulturális } \\
\text { életének általában véve ártanak, vagy } \\
\text { inkább gazdagítják, akik más országból } \\
\text { idejönnek élni? (0 azt jelenti „ártanak a } \\
\text { kulturális életnek", } 10 \text { pedig azt „gazda- } \\
\text { gítják a kulturális életet”) }\end{array}$ & $\begin{array}{l}\text { skálaértékek } \\
\text { 0-tól 3-ig }\end{array}$ & $\begin{array}{l}\text { skálaértékek } \\
\text { 4-től 6-ig }\end{array}$ & $\begin{array}{l}\text { skálaértékek } \\
\text { 7-től 10-ig }\end{array}$ \\
\hline $\begin{array}{l}\text { Rosszabb, vagy jobb hely lett-e [adott } \\
\text { ország] azzal, hogy más országból idejöt- } \\
\text { tek emberek élni? ( } 0 \text { azt jelenti „rosszabb } \\
\text { lett”, } 10 \text { pedig azt „jobb lett”) }\end{array}$ & $\begin{array}{l}\text { skálaértékek } \\
\text { 0-tól 3-ig }\end{array}$ & $\begin{array}{l}\text { skálaértékek } \\
\text { 4-től 6-ig }\end{array}$ & $\begin{array}{l}\text { skálaértékek } \\
\text { 7-től 10-ig }\end{array}$ \\
\hline
\end{tabular}

Forrás: ESS 8 adatai alapján szerzői szerkesztés

2. táblázat. A Másikhoz való viszonyulás alapján létrehozott csoportok

\begin{tabular}{lc}
\hline Csoport & Kompozit indexértékek \\
Nacionalista én/Mi-fókuszúak & 0-tól 4-ig \\
Ambivalensek & 5-től 7-ig \\
Kozmopolita önmeghaladók & 8-tól 12-ig \\
\hline
\end{tabular}

Forrás: ESS 8 adatai alapján szerzői szerkesztés

A 3. táblázat azt mutatja meg, hogy a teljes, 18 európai uniós tagállamot tartalmazó mintán, milyen megoszlásban vannak nacionalista én/Mi-fóku- 
szúak, ambivalensek, s kozmopolita önmeghaladók. Mint az az adatokról leolvasható: a kozmopoliták adják a legnagyobb csoportot, a megkérdezettek $53 \%$-a tartozik ide.

3. táblázat. A három csoport megoszlása $(\mathrm{N}=31987)$

\begin{tabular}{llrrc}
\hline \multirow{2}{*}{ Érvényes } & \multicolumn{1}{c}{$\mathrm{N}$} & $\%$ & Érvényes \% \\
\cline { 3 - 5 } & Nacionalista én/Mi-fókuszúak & 5425 & 15,3 & 17,0 \\
& Ambivalensek & 9498 & 26,8 & 29,7 \\
& Kozmopolita önmeghaladók & 17064 & 48,1 & 53,3 \\
& Összes & 31987 & 90,2 & 100,0 \\
Hiányzó & System & 3463 & 9,8 & \\
Összes & & 35450 & 100,0 & \\
\hline
\end{tabular}

Forrás: ESS 8 adatai alapján szerzői szerkesztés

A 4. táblázat foglalja össze, hogy az egyes tagállamok esetében milyen megoszlással vannak jelen a társadalomban nacionalista én/Mi-fókuszúak, ambivalensek, valamint kozmopolita önmeghaladók.

4. táblázat. A három csoport megoszlása a vizsgált 18 tagállamban (\%)

\begin{tabular}{lccc}
\hline & $\begin{array}{c}\text { Nacionalista én/ } \\
\text { Mi-fókuszúak }\end{array}$ & Ambivalensek & $\begin{array}{c}\text { Kozmopolita } \\
\text { önmeghaladók }\end{array}$ \\
\hline Svédország & 3,1 & 14,1 & 82,8 \\
Hollandia & 2,7 & 18,0 & 79,3 \\
Spanyolország & 4,9 & 18,2 & 76,9 \\
Írország & 6,4 & 20,7 & 72,9 \\
Egyesült Királyság & 6,2 & 22,1 & 71,7 \\
Finnország & 6,8 & 22,2 & 71,0 \\
Belgium & 6,6 & 27,0 & 66,4 \\
Németország & 8,0 & 25,8 & 66,2 \\
Portugália & 8,5 & 25,6 & 65,9 \\
Franciaország & 11,6 & 30,8 & 57,6 \\
Ausztria & 19,0 & 33,9 & 47,1 \\
Szlovénia & 27,1 & 33,7 & 39,2 \\
Lengyelország & 20,9 & 40,5 & 38,6 \\
Észtország & 27,0 & 37,2 & 35,8 \\
Olaszország & 35,1 & 36,3 & 28,6 \\
Csehország & 30,4 & 45,2 & 24,4 \\
Litvánia & 34,6 & 45,4 & 20,0 \\
Magyarország & 51,5 & 34,9 & 13,6 \\
\hline
\end{tabular}

Forrás: ESS 8 adatai alapján szerzői szerkesztés 
Mindenképpen említésre érdemes, hogy a magyar társadalom többsége nacionalista én/Mi-fókuszú (51,5\%), miközben további 34,9\% ambivalens, azaz több mint 86\% távolságtartó ideákat vall az önmeghaladásra késztető, változásra való nyitottságot előfeltételező Másikról. Érdemes összehasonlításképpen a táblázat elejére ugrani a svéd adatokhoz, amelyek szerint az északi nemzet társadalmának 82,8\%-a kozmopolita, s mindössze 3,1\% a nacionalisták aránya. E két markáns ellenpont mellett, ami első ránézésre szembeötlő, az a volt szocialista országok tömörülése a lista alján. Egyetlen keleteurópai társadalomban sem éri el a kozmopolita önmeghaladók aránya a $40 \%$-ot, miközben a nacionalisták hányada mindenütt 20\%, de inkább 30\% feletti. A 18 vizsgált tagállam esetében négy-öt csoportot lehet elkülöníteni. Egyfelől vannak a 70\% feletti kozmopolitákkal és 7\% alatti nacionalistákkal bíró országok (Svédország, Hollandia, Spanyolország, Írország, Egyesült Királyság és Finnország), amelyekben az ambivalensek aránya 14-22\% között mozog. Hozzájuk még nagyon hasonlóak a kétharmad körüli kozmopolitákkal és 10\% alatti nacionalistákkal bíró országok (Belgium, Németország és Portugália), amelyekben az ambivalensek aránya viszont már $25 \%$ feletti. E társadalmak esetében tehát már tapasztalható valamiféle távolságtartás a Másiktól. Egyértelmû választóvonal az adatsorban Franciaország és Ausztria esete. Az ambivalensek aránya mindkét országban egyharmad körüli, ellenben míg a francia társadalomban $57,6 \%$ a kozmopoliták és $11,6 \%$ a nacionalisták hányada, Ausztriában már kisebbségben vannak a kozmopoliták. Végezetül a lista alján a már említett kelet-európai országok vannak (Szlovénia, Lengyelország, Észtország, Csehország és Litvánia), Magyarországgal egyetemben, amely jelentősen eltér még e társadalmaktól is a nacionalista én/Mifókuszú gondolkodásmód tekintetében. Egyetlen nyugat-európai nemzet, Olaszország van e táboron belül.

Az elemzés következő része a három csoportba sorolt válaszadók jellemző értékkészleteit tárja fel. Ehhez az ún. Schwartz-tesztet használja, egész pontosan az ESS-ben lekérdezett, 21 itemes értékportré-kérdéssort. Ezen, önkitöltős kérdőívben portrékat mutatnak be, s a válaszadóknak egy hat fokú skálán kell értékelniük, hogy az adott leírás mennyire hasonlít hozzájuk. Az egyéni értékkészletet a relatív fontosság szerint szükséges értelmezni, vagyis a válaszadó összevont átlagához viszonyítjuk az egyes értékek individuális preferálását. Ez az alábbi táblázatban úgy jelenik meg, hogy 0 az átlag, a negatív tartományban lévő értékek alulpreferáltak (inkább elutasítottak), míg a pozitív tartományban lévők pedig preferáltak (erôsebb a velük való azonosulás). 
5. táblázat. A három csoportba tartozók jellemző értékkészletei

\begin{tabular}{lrlrlr}
\hline \multicolumn{2}{c}{$\begin{array}{c}\text { Nacionalista } \\
\text { én/Mi-fókuszúak }\end{array}$} & \multicolumn{2}{c}{ Ambivalensek } & \multicolumn{2}{c}{$\begin{array}{c}\text { Kozmopolita } \\
\text { Önmeghaladók }\end{array}$} \\
\hline Biztonság & 0,6517 & Jóindulat & 0,6169 & Jóindulat & 0,8146 \\
Jóindulat & 0,4933 & Biztonság & 0,5340 & Univerzalizmus & 0,6673 \\
Univerzalizmus & 0,3355 & Univerzalizmus & 0,4088 & Önállóság & 0,5130 \\
Tradíció & 0,2711 & Önállóság & 0,3251 & Biztonság & 0,2488 \\
Önállóság & 0,1971 & Tradíció & 0,1224 & Hedonizmus & $-0,0374$ \\
Konformitás & 0,0011 & Konformitás & $-0,1179$ & Tradíció & $-0,0734$ \\
Elismerés & $-0,3251$ & Hedonizmus & $-0,2189$ & Konformitás & $-0,3928$ \\
Hedonizmus & $-0,3893$ & Elismerés & $-0,3961$ & Elismerés & $-0,4891$ \\
Hatalom & $-0,6277$ & Ösztönzés & $-0,6643$ & Ösztönzés & $-0,5125$ \\
Ösztönzés & $-0,7754$ & Hatalom & $-0,8144$ & Hatalom & $-1,0720$ \\
\hline
\end{tabular}

Forrás: ESS 8 adatai alapján szerzői szerkesztés

Az adatok értelmezése előtt fontos leszögezni: a Schwartz-tesztnek vannak ún. általánosított tendenciái. Ilyen például az, hogy az univerzalizmus, a jóindulat, az önállóság, s a biztonság általában a preferált értékek közé tartozik minden embercsoportban, míg a hatalom, elismerés, s ösztönzés pedig inkább az elutasítottak közé. Mindezt figyelembe véve, sokkal lényegesebb ezért a preferálás/elutasítás mértékére koncentrálni! Mit láthatunk tehát az 5. táblázat adatait olvasva? Egyrészt azt, hogy a kozmopoliták körében az univerzalizmus (0,6673) és az önállóság $(0,5130)$ - a feltételezettek szerint - valóban sokkal inkább preferált értékek, mint az ambivalensek $(0,4088$ és 0,3251) és a nacionalisták (0,3355 és 0,1971) esetében. Még a jóindulat, vagyis a szúkebb társas közeggel való azonosulás, e csoport tagjairól való gondoskodás, illetve a rájuk való empatikus odafigyelés vonatkozásában is megvan a három csoport között ugyanez a különbség. Másfelől - a hipotézist követve - szintén kimutatható, hogy a nacionalisták sokkal inkább preferálják (kevésbé utasítják el) a hatalom $(-0,6277)$ és a biztonság $(0,6517)$ értékeit, mint az ambivalensek $(-0,8144$ és 0,5340), nem beszélve a kozmopolitákról (-1,0720 és 0,2488). Mindezek mellett érdemes még egy pillantást vetni a tradíció és konformitás értékeire is: mindegyik csoport esetében a tradíció a preferáltabb (kevésbé elutasított), de míg a nacionalisták esetében mindkét érték a pozitív tartományban szerepel, addig a kozmopoliták mindkettőt inkább elutasítják. Összességében tehát megállapítható, hogy a három csoportba tartozó válaszadók értékkészletei alapvetően eltérnek, mégpedig a várakozásoknak megfelelően.

Utolsó lépésként a három csoportba tartozók európaiságát, azaz Európával való azonosulását igyekszik feltérképezni a tanulmány. Ehhez négy változót 
használ az ESS-ből. (1) „Ön mennyire kötődik érzelmileg Európához?” A válaszadók egy 0-10-es skálán fejezhették ki kötődésüket, ahol a 0 azt jelentette „egyáltalán nem kötődök érzelmileg”, a 10 pedig azt "nagyon kötődök érzelmileg”. (2) "Az Európai Unióval kapcsolatban vannak, akik azt mondják, az integrációnak tovább kell folytatódnia. Mások szerint az Európai Unió már így is túlságosan egységesített. Kérem, helyezze el véleményét a skálán!" Szintén 0-10-es skála: 0 - „Már így is túlságosan egységesített”, 10 - „Az integrációnak tovább kell folytatódnia”. (3) „Képzelje el, hogy [a válaszadó saját országában] holnap népszavazást tartanak az európai uniós tagságról. Ön arra szavazna, hogy [saját országa] maradjon az Európai Unió tagja, vagy arra, hogy lépjen ki?" Válaszok két kategóriába újrakódolva: 1 - „Maradjon az EU tagja”, 0 - egyéb (az 1-hez közelebbi érték tehát erősebb azonosulást jelent Európával). (4) „Ön mennyire bizik az Európai Parlamentben?" 0-10-es skála: 0 - „egyáltalán nem bízik”, 10 - „teljes mértékben megbízik" (6. táblázat). Mint ismeretes, a tanulmány úgy érvelt, a nacionalisták európaisága sokkal korlátozottabb, mivel identitásukat inkább egyrétegüként, a középpontba helyezett énre, illetve annak kivetüléseként, az imaginárius Mire szúkítik, s így parciálisabb keretekbe zárják. Nem ismerik el a Másikat, ám ezzel nemcsak embertársaik szubjektivitását vitatják el, hanem önmaguk egyéniségét is behatárolják. A megkülönböződés (mi nem vagyok) elhomályosítja a felvállalható, megalkotható elméleti pozíciókat (mi vagyok). Ezen alapsémával, azaz a vagy-vagy gondolkodásmóddal szemben a kozmopolita mind-mind a többrétegúség bázisa. A Másik elismerésével az embertársi közös az, ami önmeghaladó módon és a diverzitás jegyében szorgalmazza az én szubjektivitásának, autonóm egyéniségének kibontakozását. Ennek pedig egyik rétege maga az európaiság is.

6. táblázat. Az Európával való azonosulás a három csoporton belül

\begin{tabular}{|c|c|c|c|c|}
\hline Csoportok & $\begin{array}{c}\text { Érzelmi } \\
\text { azonosulás } \\
\text { Európával }(0-10)^{1}\end{array}$ & $\begin{array}{l}\text { EU-integráció } \\
\text { megítélése } \\
(0-10)^{2}\end{array}$ & $\begin{array}{c}\text { Kilépés/ } \\
\text { maradás } \\
\text { EU-ban }(0-1)^{3}\end{array}$ & $\begin{array}{c}\text { Európa } \\
\text { Parlament } \\
\text { bizalom }(0-10)^{4}\end{array}$ \\
\hline $\begin{array}{l}\text { Nacionalista } \\
\text { én/Mi- } \\
\text { fókuszúak }\end{array}$ & 5,08 & 3,52 & 0,4500 & 3,41 \\
\hline Ambivalensek & 5,51 & 4,57 & 0,5619 & 4,08 \\
\hline $\begin{array}{l}\text { Kozmopolita } \\
\text { önmeghaladók }\end{array}$ & 6,22 & 5,70 & 0,7174 & 4,93 \\
\hline \multicolumn{5}{|c|}{$\begin{array}{l}{ }^{1} \text { Welch }=506,813, p=0,000 ;{ }^{2} \text { Welch }=1493,393, p=0,000 ;{ }^{3} \text { Welch }=1379,170, p=0,000 \\
{ }^{4} \text { Welch }=204,625, p=0,000\end{array}$} \\
\hline
\end{tabular}

Forrás: ESS 8 adatai alapján szerzői szerkesztés 
A 6. táblázat adatai szerint, az elméleti várakozásoknak megfelelően, valóban növekszik az Európával való azonosulás a kozmopolita szemlélettel, azaz az önmeghaladók lényegesen európaiabbnak vélik önmagukat. A különbségek minden változó esetében szignifikánsak az egyes csoportok között. Mindez tehát megerősíti azt az okfejtést, miszerint a kétféle, egymással rivalizáló Európa-finalitás, vagyis a normatív integrációs elméletekben szintetizálódó Európai Egyesült Államok, illetve a leíró jellegú teoretikus alapokat használó Nemzetek Európája, olyan koherens ideák, amelyek eltérő gondolkodásmódokra épülnek, s különböző értékalapozottsággal bírnak. Ám míg előbbi az európaiságot identitás szintjén is elősegíti, addig utóbbiról ez kevésbé mondható el, hiszen az egyrétegűség partikularitásait erősíti fel.

\section{ÖSSZEGZÉS}

A tanulmány nem következtetések levonását, inkább a diszkusszió fontosságát emeli ki zárógondolatai között. Az adatok alapján látszik, hogy az egyének eltérő értékpreferenciáiból eltérő gondolkodásmódok épülnek fel, s e szubjektivitások különböző azonosulásokat tesznek lehetővé Európával: az önmeghaladásra és a változásra nyitott kozmopoliták esetében egy identitási többrétegúséget, amelybe sokkal hangsúlyosabban belefér az európaiság, míg az ént, illetve az énből kivetített kollektív Mit középpontba állító, kiszámíthatóságot és stabilitást kereső nacionalisták esetében az önazonosság jellemzőbb egyrétegüségét, s az európaiság mérsékeltebb megélését. Önmagában ez persze nem új és eredeti megállapítás. Arra azonban már érdemes figyelmet fordítani, hogy a normatív és leíró típusú integrációs elméletek Európa-finalitással kapcsolatos érveléseiben ugyanígy kirajzolódik e kozmopolita/nacionalista gondolkodásmódok és értékalapozottságok nehézkes összeegyeztethetősége. Annyiban ez sem meglepő, hogy minden elméletadó szubjektív egyén, akiktől nem lehet „érintetlenséget” követelni. Ugyanakkor kevéssé előremutató, ha a tudományos eszmék és az azokról szóló diskurzusok - a reflexivitást mellőzve - csak reproduktív értelemben képesek reflektálni a politikai-közéleti ideákra és kommunikációs interakciókra, legfeljebb minimálisan változtatva így az elvárások és választások horizontján, valamint az azok tükrében lehetséges döntések tapasztalati terén.

\section{KÖSZÖNETNYILVÁNÍTÁS}

Jelen munka az NKFIH által támogatott „Az Európai Unió normatív szerepvállalása" címú kutatás része (a PD124706 számú projekt a Nemzeti Kutatási Fejlesztési és Innovációs Alapból biztosított támogatással, a PD17 pályázati program finanszírozásában valósult meg). 


\section{IRODALOM}

Arató Krisztina (2019): Integrációelméletek (történelmi perspektívában). In: Arató Krisztina-Koller Boglárka (szerk.): Az Európai Unió politikai rendszere. Budapest, Dialóg Campus.

Balibar, Etienne (2003): We, the people of Europe? Reflections on transnational citizenship. Princeton, Princeton UP.

Beck, Ulrich (2006): Cosmopolitan vision. Cambridge, Polity.

Beck, Ulrich-Grande, Edgar (2007): Kozmopolita Európa: társadalom és politika a második modernitás korszakában. Budapest, Belvedere Meridionale.

Beck, Ulrich-Anthony Giddens-Scott Lash (1994): Reflexive modernization. Politics, tradition and aesthetics in the modern social order. Cambridge, Polity.

Bóka Éva (2001): Az európai egységgondolat fejlódéstörténete. Budapest, Napvilág Kiadó.

Brons, Lajos (2015): Othering, an Analysis. Transcience, Vol. 6, No. 1, 69-90.

Burgess, Michael (2000): Federalism and the European Union: Building of Europe 1950-2000. London, Routledge.

Cini, Michelle (2007): Inter-governmentalism. In: Michelle Cini (ed.) European Union politics. Oxford, Oxford UP.

Collier, Andrew (1994): Critical realism: An introduction to Roy Bhaskar's philosophy. London, Verso.

Delanty, Gerard-Chris Rumford (2005): Rethinking Europe: Social Theory and the Implications of Europeanization. Abingdon-New York, Routledge.

DiMaggio, Paul J.-Walter W. Powell (1991): Introduction In: DiMaggio, Paul J.-Powell, Walter W. (szerk.): The new institutionalism in organizational analysis. Chicago, Chicago UP.

Fiori, Stefano (2002), Alternative visions of change in Douglass North's new institutionalism. Journal of Economic Issues, Vol. 36, No. 4, 1025-1043. https://doi.org/10.1080/00213624.2002.11506 534

Grünhut, Zoltán (2017): Concepts, approaches and methods on Europeanisation. Eastern Journal of European Studies, Vol. 8, No. 1, 157-176.

Grünhut, Zoltán (2019a): Europeanization: A critical realist, discursive institutionalist approach. Modelling the New Europe, Vol. 8, No. 29. 4-24.https://doi.org/10.24193/ojmne.2019.29.01

Grünhut, Zoltán (2019b): Reflexive Europe and the era of Late Modernity. Acta Baltica Historiae et Philosophiae Scientiarum, Vol. 7, No. 3, 42-57. https://doi.org/10.11590/abhps.2019.3.03

Grünhut, Zoltán (2019c): Recognizing the Other as a test of Europeanness. The value-based foundations of individual reflexivity in the era of Late Modernity. Europolity, Vol. 13, No. 2, 125-147. https://doi.org/10.25019/europolity.2019.13.2.6

Grünhut Zoltán-Kömüves Dániel-Bodor Ákos (2019a): A bizalomelmélet kritikai újragondolása az eldologiasodás szempontjából. Replika, Vol. 30, No. 113, 11-24.

Grünhut Zoltán-Bodor Ákos-Pirmajer Attila (2019b): A bizalom és az alapvető emberi értékek összefüggése. Replika, Vol. 30, No. 113, 45-60. https://doi.org/10.32564/113.4

Guzzini, Stefano (2017): Realist theories and practice. Danish Institute for International Studies, Working Paper, 2017/8.

Habermas, Jürgen (2006): A posztnemzeti állapot. Budapest, L'Harmattan.

Habermas, Jürgen (2009): Europe. The faltering project. London, Polity. 
Habermas, Jürgen (2012): The crisis of the European Union. London, Polity.

Hall, Peter A.-Taylor, Rosemary C. (1996): Political science and the three institutionalisms. Political Studies, Vol. 44, No. 5, 936-957. https://doi.org/10.1111/j.1467-9248.1996.tb00343.x

Honneth, Axel (1995): The struggle for recognition: The moral grammar of social conflicts. London, Polity.

Honneth, Axel (2007): Reification: A recognition-theoretical view. Oxford, Oxford UP.

Jaeggi, Rachel (2014): Alienation. New York, Columbia UP.

Kapitány Ágnes-Kapitány Gábor (2013): Szellemi termelési mód. Budapest, Kossuth.

Koller Boglárka (2012): Klubtagságok az EU-ban. A differenciált integráció gyakorlati és elméleti vonatkozásai. Politikatudományi Szemle, Vol. 21, No. 1, 32-57.

Koller Boglárka (2019): Többsebességes vagy menüválasztásos jövő? A differenciált integráció elméleti és gyakorlati kérdései az Európai Unióban. In: Halmai Péter (szerk.): Tagállami integrációs modellek. Budapest, Dialóg Campus Kiadó.

Lukács György (1971): Történelem és osztálytudat. Budapest, Gondolat.

March, James G.-Olsen, Johan P. (1989): Rediscovering institutions. The organizational basis of politics. New York, Free Press.

Moravcsik, Andrew (1994): Why the European community strengthens the state: Domestic politics and international cooperation. Harvard University Centre for European Studies Working Papers, No. 52,

Moravcsik, Andrew (1998): The choice of Europe: Social purpose and state power from Messina to Maastricht. London, UCL.

Nugent, Neill (1999): The government and politics of the European Union. Basingstoke, Palgrave.

Rorty, Richard (1979): Philosophy and the mirror of nature. Princeton, Princeton UP.

Rorty, Richard (1989): Contingency, Irony and Solidarity. Cambridge, Cambridge UP.

Rorty, Richard (1991): Objectivity, relativism and truth: Philosophical papers I. Cambridge, Cambridge UP.

Rorty, Richard (1998): Truth and progress: Philosophical papers III. Cambridge, Cambridge UP.

Rosamond, Ben (2000): Theories of European integration. Basingstoke, Palgrave.

Rumford, Chris (2007): Cosmopolitanism and Europe. Liverpool, Liverpool UP.

Rumford, Chris (2008): Cosmopolitan spaces: Europe, globalization, theory. Abingdon-New York, Routledge.

Schmidt Vivien A. (2008): Discursive institutionalism: The explanatory power of ideas and discourse. Annual Review of Political Science, No. 11, 303-326. https://doi.org/10.1146/annurev. polisci.11.060606.135342

Schmidt, Vivien A. (2010): Taking ideas and discourse seriously. European Political Science Review, Vol. 2, No. 1, 1-25. https://doi.org/10.1017/s175577390999021x

Schmidt, Vivien A. (2017): Theorizing ideas and discourse in political science. Critical Review, Vol. 29, No. 2, 248-263. https://doi.org/10.1080/08913811.2017.1366665

Schwartz, Shalom H. (1992): Universals in the content and structure of values: Theory and empirical tests in 20 countries In: Mark P. Zanna (ed): Advances in Experimental Social Psychology (25). New York, Academic Press. 
Schwartz, Shalom H. (2005): Basic human values: Their content and structure across countries In: Tamayo, Alvaro-Porto, Julianna B. (szerk.): Valores e comportamento nas organizações. Petrópolis, Vozes.

Schwartz, Shalom H. (2006): Basic human values: Theory, measurement, and applications. Revue française de sociologie, Vol. 47, No. 4, 929-968.

Schwartz, Shalom H.-Wolfgang Bilsky (1987): Toward a psychological structure of human values. Journal of Personality and Social Psychology, Vol. 53, No. 3, 550-562. https://doi.org/10.1037/00223514.53.3.550

Schwartz, Shalom H.-Wolfgang Bilsky (1990): Toward a theory of the universal content and structure of values: Extensions and cross-cultural peplications. Journal of Personality and Social Psychology, Vol. 58, No. 5, 878-891. https://doi.org/10.1037/0022-3514.58.5.878

Shepsle, Kenneth A. (2005): Rational choice institutionalism. Cambridge, Harvard UP.

Sik Domonkos (2018): Adalékok az eldologiasodás fenomenológiájához. Replika, Vol. 28, No. 108109, 79-95. https://doi.org/10.32564/108-109.6

Stroby-Jensen, Carsten (2007): Neo-functionalism In: Cini, Michelle (ed.): EU politics. Oxford, Oxford UP.

Vandenberghe, Frédéric (2014): What's critical about critical realism? Abingdon-New York, Routledge.

Weingast, Barry R. (1998): Political institutions: Rational choice perspectives. In: Goodin, Robert E.-Klingemann, Hans-Dieter (szerk.): A new handbook of political science. Oxford, Oxford UP.

Weiss János (2008): Az eldologiasodás elismeréselméleti értelmezése. Fordulat, Vol. 1, No. 1, 145150.

Wiener, Antje és Thomas Diez (szerk.): European integration theory. Oxford-New York, Oxford UP. 